\title{
Desafiar Mamon: O Estado das Contas Públicas
}

\author{
Challenging Mammon: The State of Public Accounts
}

\author{
JOSÉ EMANUEL MATOS TORRES'
}

GALILEU - REVISTA DE DIREITO E ECONOMIA - e-ISSN 2184-1845

Volume XIX $\cdot 1^{\text {st }}$ July Julho $-31^{\mathrm{TH}}$ December Dezembro $2018 \cdot$ pp. 100-130

DOI: https://doi.org/10.26619/2184-1845.XIX.2.5

Submitted on July $2^{\text {th }}, 2018$. Accepted on November 11 $11^{\text {th }}, 2018$

Submetido em 2 de Julho, 2018. Aceite a 11 de Novembro, 2018

RESUMO Vivemos hoje tempos de grande euforia económica. As exportações crescem significativamente, muito à boleia do turismo, o investimento dá sinais de querer emergir, o desemprego desce, a inflação está controlada. No setor público atinge-se o défice mais baixo desde o antigo regime. Tudo parece estar a correr bem. Mas será que sim?

A «besta negra» das contas nacionais, a dívida pública, não para de crescer em termos absolutos e relativos. Esse comportamento poderia não ser tão preocupante se estivéssemos certos que os motivos que estão por detrás fossem virtuosos. Mas os dados apontam em sentido contrário. Efetivamente, não é só o stock de dívida e os inerentes encargos que merecem preocupação. Mais importante que tudo é a sua origem, natureza e composição. As contas públicas sofrem o efeito de um vírus silencioso, ainda assintomático, que corrói a sua sustentabilidade, na linha do preconizado pelos clássicos, como Keynes - com a sua teoria da regra de ouro orçamental, tão ignorada que é - e, entre nós, José Teixeira Ribeiro. E ninguém parece querer ligar a isso.

Os mecanismos e as regras de controlo assumidas pela UE, para além das dúvidas na sua cientificidade, bondade e eficácia, não obrigam a recentrar a questão no essencial. Por isso muito terá que ser feito a nível interno para obstar aquilo que parece inevitável, se a situação não se inverter: a perda sistemática da soberania financeira nacional, podendo culminar no quarto resgate financeiro da era democrática.

PalaVRas-chave Dívida Pública. Dívida interna e externa. Regra de ouro do orçamento de Keynes. Soberania financeira nacional. Controlo das contas públicas. Pacto de Estabilidade e Crescimento da União Europeia.

1 Licenciado em Ciências Policiais e em Gestão. Diretor Nacional Adjunto para a Unidade Orgânica de Logística da PSP 
ABSTRACT We live in times of great economic euphoria. Exports grow significantly, much thanks to the tourism industry, investment appears to be emerging, unemployment is falling, and inflation is controlled. The public sector has reached the lowest deficit since the old regime. Everything seems to be going well. But is it?

The "black beast" of national accounts, public debt, has not ceased to grow in absolute and relative terms. This behaviour might not be so disturbing if we were certain that the motives behind it were good. But the data points to the opposite direction. Effectively, it is not just the debt stock and the inherent problems that deserve concern. More important than anything is its origin, nature and composition. Public accounts suffer from a silent virus, still asymptomatic, which erodes its sustainability, along the line of the classics, as Keynes - with his theory of the budget golden rule, much ignored - and our own José Teixeira Ribeiro. And no one seems to care.

The mechanisms and control rules adopted by the EU, in addition to doubts as to their scientific, worthy and effective nature, do not require a reorientation of the question in its main points. So, much will have to be done internally to prevent what seems inevitable if the situation is not reversed: the systematic loss of national financial sovereignty, which could culminate in the fourth financial bailout of the democratic era.

KEYWORDS Public Debt. Internal and external debt. Keynes Budget Golden Rule. National financial sovereignty. Control of public accounts. Stability and Growth Pact of the European Union.

\section{Introdução}

Portugal assiste atualmente a uma transformação socioeconómica de grande significado, ancorada no aumento da produtividade, na capacidade de inovação e numa maior competitividade à escala mundial, não tanto pela quantidade produzida - não apresenta grande disponibilidade de fatores de produção nem um mercado interno significativo, depois da perda do efeito escala que detinha com as ex-colónias -, mas sim pela subida dos seus produtos na cadeia de valor acrescentado.

Para ser bem-sucedido neste duro caminho do sucesso económico, o único que pode gerar bem-estar e tranquilidade aos cidadãos residentes, o país precisa de facto de contas públicas estabilizadas e controladas. Só assim conseguirá aliviar o elevado esforço que exige aos agentes económicos sob a forma de impostos, taxas e outras contribuições, embora indubitavelmente ainda exista espaço para melhorar os índices de eficácia e eficiência fiscal e de aliviar a despesa corrente. 
O ano de 2016, no que toca ao défice orçamental, foi o melhor de sempre desde a implantação da democracia. É, sem dúvida alguma, motivo para regozijo, para mais quando outros indicadores de cariz socioeconómico, como o desemprego, a criação de riqueza e as exportações tiveram melhorias substanciais, significando afinal que, como dizíamos há tempos², havia alternativas a uma linha austeritária ortodoxa. Mas os velhos problemas orçamentais, desde logo a inexistência de forma continuada de superavits correntes e o enorme stock de dívida pública, em especial os efeitos que emergem da sua peculiar natureza e origem, continuam a provocar enormes dores de cabeça aos sucessivos governantes. Como iremos procurar demonstrar, o desempenho orçamental do Estado tem, ao longo destas últimas quatro décadas, sofrido os efeitos de um vírus nocivo, silencioso, que se fortalece continuamente, mesmo de forma assintomática.

A sujeição severa a regras inscritas quer no Pacto de Estabilidade e Crescimento (PaEC) quer no Tratado Orçamental (TO), aceites dogmaticamente pelo establishment europeu, pode não ser assim tão tranquilizadora. Demonstraremos as nossas dúvidas quanto à sua lógica e virtuosidade. Na verdade, ninguém discute a necessidade de haver regras num espaço europeu com moeda única. Mas quando tal implica sacríficos brutais aos povos europeus, em especial nos países com menor dimensão económica, a sua consistência, credibilidade e validade científica têm de ser absolutamente «à prova de bala». Analisemos para já a trajetória do nosso maior problema à luz das mesmas regras: a dívida soberana.

\section{Como evoluiu a dívida pública até hoje}

Por altura da eclosão generalizada da crise financeira iniciada nos EUA, em 2008, apenas Grécia (109\% do PIB), Itália (102\%) e Bélgica (92\%) registavam dívidas soberanas superiores a $90 \%{ }^{3}$. Dois dos periféricos de certo modo intervencionados - Irlanda e Espanha - tinham níveis de dívida face ao PIB - 43\% e 39\%, respetivamente - claramente dentro dos parâmetros prescritos no PaEC, ao contrário do valor médio na altura verificado na zona euro (69\%) e na própria Alemanha $(65 \%)^{4}$. Este facto, só por si, põe em causa a tese de que a origem dessa hecatombe financeira tenha sido o excesso de endividamento público, ignorando que essencialmente se tratou de um desmoronamento do sistema financeiro por erros crónicos de gestão estratégica e operacional, em especial na avaliação do risco de mútuo e de investimento ${ }^{5}$. Na verdade, uma boa parte da dívida pública hoje existente em países desenvol-

\footnotetext{
2 José Torres, Não Temos de Ser Alemães, Editora Matéria-Prima, Lisboa, 2014

3 Bank for International Settlements, 2015.

4 A qual está desde 2002 acima do teto dos $60 \%$ / PIB.

5 Que originou igualmente um excessivo endividamento privado, empresas e famílias.
} 
vidos resulta diretamente do efeito de contaminação de dívida privada tóxica, nomeadamente com origem na banca ${ }^{6}$. De acordo com os dados mais recentes do Eurostat ${ }^{7}$, Portugal foi um dos países europeus que mais gastou com apoios ao setor financeiro entre 2008 e 2016, totalizando 12,9 mil milhões de euros (7\% do PIB), só tendo sido ultrapassado pela Irlanda (17,6\% do PIB), Grécia (15,6\%), Eslovénia (13,5\%) e Chipre (10,7\%).

O Estado português tinha à data um nível de dívida aceitável, na ordem dos $72 \%$ do PIB. No entanto, há que ter em atenção vários aspetos importantes: em primeiro lugar, existia muita dívida pública indevidamente fora do perímetro orçamental, nomeadamente do setor público empresarial, que teve de ser incorporada em nome de princípios de universalidade, credibilidade e uniformidade contabilística, impostos pela União Europeia (UE); em segundo, como bem refere Fernando Alexandre e outros ${ }^{8}$, numa análise dinâmica, a dívida pública portuguesa foi a que mais cresceu na UE em termos de percentagem do PIB desde a criação do euro até 2007 (exatamente 17 pontos percentuais). Se compararmos os últimos 20 anos (1995-2015), verificamos que a dívida pública portuguesa face ao PIB subiu 70,7 p.p., só sendo ultrapassada na UE pela Grécia (80,6 p.p.) $)^{9}$; por último, a evolução da riqueza produzida em Portugal, a roçar a mediocridade desde a entrada no euro, agravou as dúvidas, mesmo que meramente percetivas, da solvabilidade do Estado face a este galopante ritmo de endividamento.

Claro que depois havia outro fator crucial em Portugal, para muitos o mais importante. É que os agentes económicos em geral - empresas e famílias -, beneficiando das taxas de juro historicamente baixas e da liquidez promovida por uma globalização acima de tudo financeira, aumentaram os seus níveis de endividamento ${ }^{10}$. Pode inclusivamente falar-se de um certo aproveitamento político deste novo facilitismo financeiro, já que foram inúmeros os incentivos explícitos ou implícitos a tal, com o beneplácito governamental, como que a contrabalançar uma economia cronicamente de baixos salários. Muitos especialistas defendem mesmo que a explosão do endividamento privado antecede geralmente crises graves do ponto de vista macroeconómico, de que é exemplo o Japão, os próprios EUA e, vaticinam, a China a médio prazo. Aliás, o ainda hoje elevadíssimo nível de endividamento das empresas portuguesas, em especial de origem bancária, muito superior à média europeia e dos EUA, começa a assumir-se como o principal óbice ao recrudescimento consistente do investimento privado.

6 O facto de a dívida privada ser superior à pública mesmo depois de transferência de parte daquela para esta, não é exclusivo nacional nem sequer europeu. De acordo com um estudo recente do FMI, - Debt: Use it Wisely, Fiscal Monitor, October 2016 - o setor não financeiro mundial apresenta hoje uma dívida total de $225 \%$ do PIB, sendo que apenas um terço é dívida pública.

7 Disponível em «http://ec.europa.eu/eurostat/publications/statistical-reports».

8 Fernando Alexandre, Luis Aguiar-Conraria e Pedro Bação, Crise e Castigo, FMS, Lisboa, 2016.

9 Em boa parte, como referimos atrás, por efeito do forte apoio ao setor financeiro, em especial os bancos BPN, BES e BANIF, obviamente financiado por dívida pública.

10 De acordo com o boletim estatístico do BdP (fev2016), em 2015 o endividamento privado atingiu 225,1\% do PIB. 
Basicamente, podemos dizer que a dívida pública é mitigada através de:

1) Crescimento económico, gerando receitas fiscais adicionais que podem ser aplicadas no abatimento do stock nominal de divida ${ }^{11}$;

2) Inflação, que provoca a sua redução em termos reais;

3) Austeridade, com o objetivo de gerar excedentes e/ou sustar novos défices orçamentais;

4) Venda de ativos públicos, nomeadamente a privatização de empresas do SPE e alienação de património ${ }^{12}$.

A Inglaterra pôde em tempos experimentar a força do tão almejado crescimento económico no abatimento da dívida pública. No início do século XIX, a dívida pública britânica quase chegou aos $250 \%$ do PIB, na sequência de sucessivas guerras contra velhos inimigos, como a França e a Espanha, com o serviço da dívida a representar mais de 40\% da despesa total durante as décadas seguintes. Beneficiando de um forte dinamismo económico, em especial alicerçado nas «Revoluções Industriais», que chegou a aumentar a riqueza per capita em 500\%, em pouco mais de 40 anos baixou o nível de dívida em quase 160 pontos percentuais, uma recuperação astronómica e dificilmente repetível em condições normais.

Mas o crescimento económico não é fácil de alcançar em economias já amadurecidas, para mais com os setores público e, em especial, privado altamente endividados. Basta ver o tempo que Portugal precisaria para garantir o parâmetro consignado no PaEC dos 60\% de dívida pública relativamente ao PIB a partir do valor atual (a rondar os $130 \%$ ), mesmo que crescesse a uma taxa hoje mirífica de $3 \%$ ao ano, sem agravamento daquele stock ${ }^{13} \mathrm{e}$ «prescindindo» do efeito inflacionista: cerca de 26 anos! $!^{14}$ Por outro lado, sendo o crescimento catapultado também pelo aumento da população e respetiva produtividade, o certo é que, também neste domínio, o nosso país está em desvantagem, já que a sua população residente é hoje sensivelmente a mesma do que há 15 anos atrás, com a agravante de estar cada vez mais envelhecida ${ }^{15}$.

A França, como outros países europeus, beneficiou largamente de uma inflação elevada no período belicoso de 1913-1950, que chegou a 13\% ao ano. Mantendo-se tudo o resto cons-

$11 \mathrm{Ou}$, de forma mais virtual, mas indo ao encontro da tendência hodierna, mitigando o rácio Dívida Pública / PIB pelo aumento deste último (denominador).

12 Poderíamos ainda ter introduzido um quinto fator acerrimamente defendido pelo economista francês Thomas Piketty, na sua mais recente obra-prima (O Capital no Século XXI, $1 .{ }^{a}$ Edição, Círculo de Leitores, Lisboa, 2014) - o imposto progressivo sobre o capital privado, considerando-o como a solução mais justa e equitativa.

13 Ou seja, basicamente com saldos orçamentais equilibrados, o que nunca experimentámos em democracia.

14 Ricardo Cabral, economista da Universidade da Madeira, calculou que se seguissem as projeções do FMI para 2021, a dívida pública portuguesa só estará abaixo dos 60\% em 2113 (jornal Expresso, 29/10/2016).

15 Dados do INE / PORDATA. O que até pode não ser um problema, face à crescente automação da economia, que exponencia a produção por unidade de custo laboral. 
tante, uma inflação anual deste montante naquele lapso de tempo teria provocado uma redução real no stock da dívida pública para cerca de um centésimo do valor inicial, de forma relativamente indolor ${ }^{16}$ ! Também o Reino Unido conseguiu baixar a dívida pública em termos reais no pós-guerra - de $200 \%$ para $50 \%$ do PIB já na década de 1990 - com a preciosa ajuda da inflação registada nessa altura.

A austeridade é claramente o modo mais penoso de mitigar a dívida pública, não sendo a própria eficácia isenta de críticas nos meios académicos. O princípio em que se baseia é idêntico, a contrario, ao visado com o crescimento económico: obtenção de saldos orçamentais excedentários através do aumento da receita e, em especial, da redução da despesa pública, de forma a diminuir as necessidades de financiamento futuras e abater ao stock da dívida soberana. Na teoria funciona bem, o problema é que a realidade teima em contrariá-lo. Os portugueses sabem-no bem.

Existem dois grandes efeitos colaterais que não podem ser ignorados: por um lado, redução da despesa pública, que, para além do investimento público, acaba por recair em geral na vertente social (o chamado «Estado Social»), nomeadamente na saúde, educação e no apoio aos infortunados e carenciados, diminuindo amplamente a qualidade de vida dos cidadãos e a perceção da justeza da carga fiscal a que todos são submetidos; pelo outro, redução do rendimento disponível dos particulares por via do aumento de impostos, da mitigação da despesa fiscal e do abrandamento das transferências sociais, levando a uma menor propensão ao consumo e, deste modo, a uma espécie de círculo vicioso - medidas austeritárias, menos rendimento disponível, menos procura, investimento e crescimento, menos receitas fiscais, menos rendimento disponível, novas medidas austeritárias.

Aliás, tudo isto acabou por ser recentemente reconhecido pelo FMI numa espécie de mea culpa, na sequência das duras experimentações elevadas a cabo nos países periféricos da europa, no âmbito do seu vasto programa de austeridade ${ }^{17}$. Nada de admirar, se pensarmos bem: Portugal tem hoje um stock total de dívida pública na ordem dos 245 milhões de euros. Ora, contar primordialmente com excedentes orçamentais - realidade absolutamente desconhecida no país na era democrática - para amortizar esse volume de dívida é de facto um exercício situado no plano do imaginário.

Finalmente, temos a questão da venda de ativos públicos. Antes de mais, devemos ter em conta que o conceito de dívida pública bruta é aquele que, bem ou mal, é utilizado para efeitos de contabilidade nacional. Não deixa de ser uma forma algo enviesada de olhar para a susten- 
tabilidade financeira de um Estado, já que apenas atende aos passivos, ignorando os ativos. A verdadeira situação patrimonial e financeira de uma entidade contabilística, seja a que escala for, apura-se confrontando a totalidade dos passivos com os seus ativos, não sendo raro que, por exemplo, grandes e prósperas empresas detenham um passivo de grandes dimensões. Tal representa só um lado da realidade. De acordo com alguns autores, a dimensão da totalidade dos ativos públicos de um país ocidental, neles se incluindo infraestruturas, aplicações financeiras, reservas de ouro, etc., será grosso modo idêntica à da dívida pública bruta.

Fruto de uma herança fortemente estatizante, em que tudo girava e encontrava suporte num Estado paternalista, Portugal tem ainda hoje um amplo leque de ativos do domínio público, apesar da recente privatização de algumas das suas lucrativas empresas, que funcionavam como autênticas «vacas leiteiras», na conhecida expressão comercial. Por outro lado, de acordo com os dados do World Gold Council, Portugal terá uma das maiores reservas de ouro do mundo em termos absolutos, com cerca de 380 toneladas, correspondendo, a preços de mercado, a quase $10 \%$ do seu PIB, o maior peso relativo entre os países desenvolvidos. Sendo a sustentabilidade da dívida pública apurada, a nosso ver, pela probabilidade real (elemento objetivo) ou percecionada (elemento subjetivo) de os credores reaverem a totalidade do capital investido e correspondentes juros, este panorama dá alguma tranquilidade. Foi nesta senda que, há tempos, um alto responsável alemão afirmou, de forma algo sobranceira, que se a situação persistisse em correr mal e a Grécia tivesse dificuldades em pagar as suas dívidas poderia sempre alienar umas ilhas, o que foi muito mal interpretado. Mas é objetivamente correto pensá-lo.

$\mathrm{Na}$ impossibilidade de se socorrer do crescimento económico e da inflação para reduzir o peso da dívida soberana, o Estado português foi até há pouco tempo empurrado pelas elites europeias e mundiais para a adoção de políticas de austeridade e para a alienação de empresas públicas, algumas em regime de monopólio natural e bastante lucrativas. E as coisas não correram bem. A austeridade provocou forte contração económica, perda de rendimento e de qualidade de vida entre os portugueses e, não obstante, aumento da dívida pública. Ao mesmo tempo, as privatizações feitas em condições difíceis e de modo algo apressado, na ausência de liquidez interna, levaram à redução patrimonial do Estado com a perda dos ativos e à degradação da sua situação financeira (receitas de capital) pela perda dos dividendos. E o pior de tudo é que a redução do stock de dívida com essa alienação de ativos foi pouco mais do que irrelevante, sendo que os dividendos que se deixaram de ganhar nem sequer compensaram a diminuição dos encargos com a dívida pública decorrentes do correspondente abatimento ${ }^{18}$. 
Isto sem falar nos efeitos geopolíticos e geoeconómicos decorrentes da abdicação de algumas das chamadas empresas-bandeira ${ }^{19}$, ao prejudicar a capacidade de orientação estratégica em direção a desígnios soberanos, ficando igualmente os agentes económicos vulneráveis a padrões de preço e qualidade que o Estado não consegue controlar, por mais cuidadosos que tenham sido os contratos de privatização. Ainda está por comprovar, unicamente no plano económico, a vantagem de ter uma empresa privada ao invés de uma pública num setor não concorrencial, em especial quando revestir interesse estratégico nacional ${ }^{20}$. Isto numa altura em que se reconhece de forma inequívoca a necessidade de definir claramente uma estratégica nacional e de cimentar os vetores do investimento e das exportações ${ }^{21}$.

Reparemos agora na evolução da dívida pública (bruta), PIB e IPC em Portugal desde 1991:

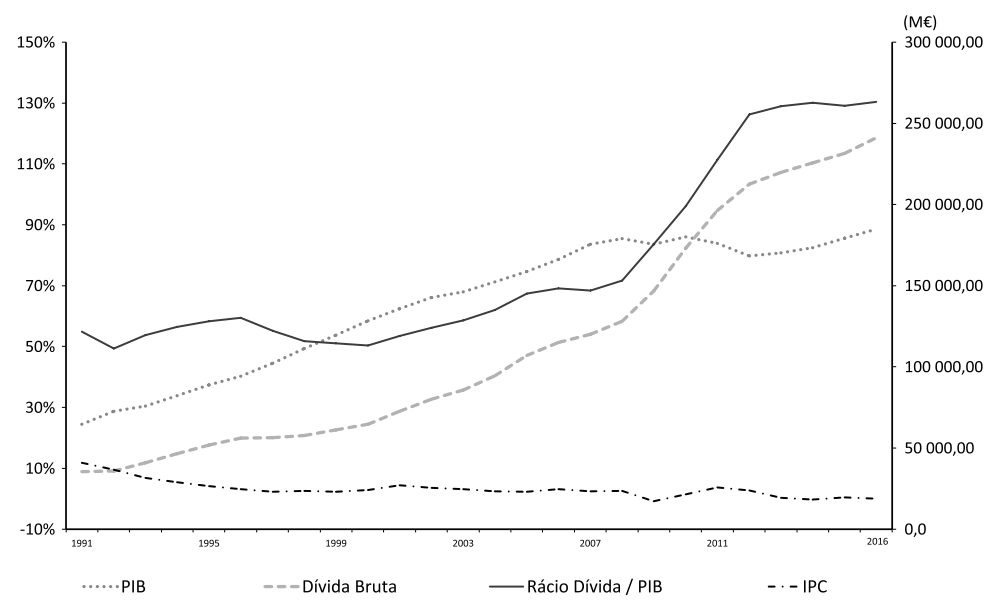

Fig. 1: Evolução da dívida pública, PIB e IPC em Portugal

(Fonte: Elaboração própria, com base nos dados primários da PORDATA)

dívida pelo abatimento daquele montante é sensivelmente igual aos dividendos potenciais em quatro meses. O abatimento da receita da venda do ativo, à volta dos cinco mil milhões de euros, acabou obviamente por se diluir nesse imenso «mar» que é o stock da dívida pública portuguesa.

19 Empresas estratégicas e simbólicas que projetam influência nacional e atuam alinhadas com as grandes orientações políticas e económicas do governo, como a TAP e, até há pouco, ANA e os CTT.

20 Talvez seja bom lembrar que grandes empresas, agora total ou parcialmente privatizadas, como a antiga PT, Galp, EDP, CTT, CIMPOR, ANA, REN, entre muitas outras, cresceram e consolidaram posições no setor público empresarial, tendo desenvolvido vasto e complexo know-how e adquirido uma dimensão e massa crítica que ainda hoje lhes conferem grandes vantagens competitivas neste mundo global.

21 De acordo com dados recentes divulgados na edição do jornal Expresso de 05/11/2016, 48\% do grupo das 500 maiores \&melhores empresas de Portugal é controlado por capital estrangeiro, contra $43 \%$ de capital privado nacional, $7 \%$ público e os restantes $2 \%$ cooperativo. 
De acordo com o mesmo, o rácio da dívida pública face ao PIB manteve-se a níveis estabilizados até 2001, altura em que começa a agravar-se de forma gradual por um duplo-efeito: por um lado, o stock da dívida retoma uma tendência de forte crescimento, evidenciado por uma curva de formato côncavo, em que as taxas de crescimento são marginalmente crescentes e, pelo outro, no que toca ao PIB, verifica-se uma quebra de uma linha evolutiva de formato côncavo para convexo sensivelmente a partir desse mesmo ano. $O$ efeito combinado resultou no disparo da dívida portuguesa em percentagem do PIB, embora se tenha mantido dentro dos níveis do PaEC até meados de 2004, sendo que até finais de 2008 foi inferior a 70\%, como vimos atrás. Por outro lado, a inflação mostrou de forma continuada uma estabilização marcadamente decrescente, situando-se atualmente em valores residuais próximos do zero, provocando um contínuo aumento real do stock da dívida pública.

Em 2016 terá atingido 130,4\% ${ }^{22}$, ultrapassando sucessivas «barreiras de sustentabilidade», se bem que esta, como já referimos atrás, mais do que um valor concreto, se traduza quanto a nós numa espécie de teto imaginário estabelecido casuisticamente em função do grau de confiança e das expetativas dos credores na sua solvabilidade ${ }^{23}$. No entanto, em abono da verdade, é preciso dizer que até 2001 a variação média do stock da dívida foi de $19 \%$ ao ano (mas genericamente decrescente ao longo dos tempos, depois dos «anos loucos» da década de 80 ), sendo que desde aquela data até 2013 baixa para 10\% / ano, mesmo influenciada pelos anos pós-crise financeira.

Seja como for, o volume de dívida pública, numa conjuntura de baixo crescimento e inflação como a atual, não deixa de ser preocupante. Para além disso, há ainda que ter em conta o stock de dívida que recai sobre entidades públicas fora do perímetro orçamental, nomeadamente do setor empresarial, o qual, apesar de não ser estatisticamente considerado nas contas de Bruxelas, pode vir a sê-lo por motivos diversos, apenas por mera decisão administrativa, como aconteceu num passado recente. Mas, mesmo que o não seja, não deixa de ser dívida pública, em bom rigor. E, segundo as contas do Banco de Portugal (BdP) e IGCP, falamos de mais de 33 pontos percentuais do PIB!

Como já referimos, Portugal teve uma trajetória de permanente agravamento da dívida pública desde há 20 anos, com especial enfase após a entrada na zona euro, como bem ilustra a fig. 2. Por exemplo, em relação à Itália, o nosso país começa com um peso de endividamento público bem inferior, acabando por estar praticamente ao seu nível em 2015. Não podemos ficar indiferentes a situações como a da Bélgica e principalmente da Suécia, que,

23 Entendida aqui como probabilidade das atuais e futuras dívidas contraídas serem integralmente pagas, juntamente com os respetivos juros e demais encargos. 
em claro contraciclo com a generalidade dos países escrutinados, conseguiram baixar o rácio de dívida pública face a 1995, aparentemente demonstrando elevado critério e ponderação na gestão das contas públicas. Aliás, parece ser uma questão cultural comungada de uma maneira ou de outra pelos restantes países do norte da Europa.

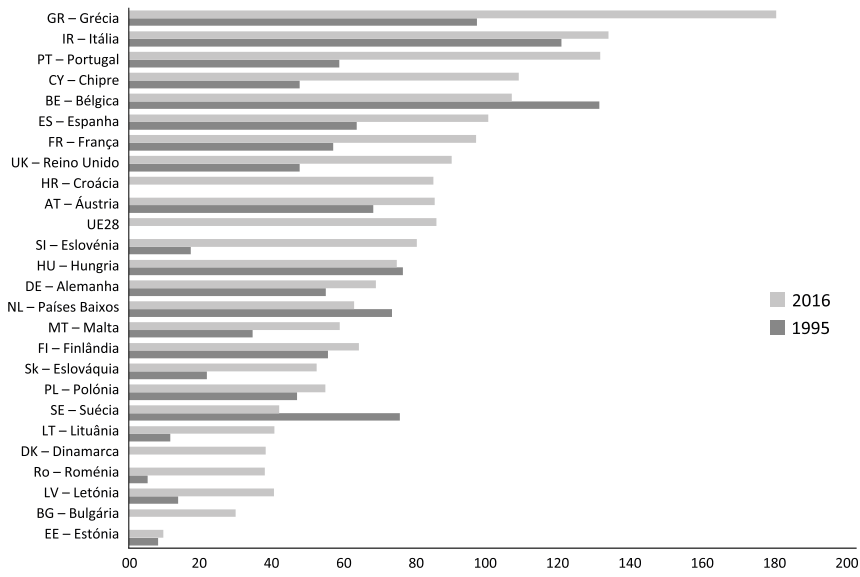

Fig. 2: Evolução da dívida pública nos países da UE desde 1995 (Fonte: Elaboração própria, com base nos dados primários da PORDATA)

Mas existe um prisma de análise que raramenteé considerado nos meios académicos enos media especializados, que não tem relação com a dívida pública bruta face à riqueza nacional produzida num ano (PIB) mas sim comparando-a com a população residente. Esta medida, grosso modo, traduz o peso potencial de impostos que pode futuramente recair sobre cada cidadão, se não se contar com outras «muletas» já faladas anteriormente, como a inflação e crescimento económico. Atentemos então no gráfico seguinte, contendo dados relativos a 2014.

Como podemos verificar, sob este prisma, Portugal não é dos países que «oferecem» aos seus cidadãos um maior peso de dívida pública. Está abaixo de países de referência da economia mundial, como por exemplo o inevitável Japão, os EUA, Canadá, Reino Unido, Holanda e Noruega. Há que reconhecer que a realidade pode ser uma, mas tem sempre várias formas possíveis de ser lida e interpretada.

Para além disso, nem sempre a contração de dívida pública é uma decisão genericamente adversa para os cidadãos. Pode até ser a mais justa e acertada, mesmo quando os fundos disponíveis no momento a dispensassem. Na verdade, ela pode ser aconselhável por razões de equidade intergeracional (distribuir custos de investimento por diferentes gerações de contribuintes), para antecipar investimentos necessários para o desenvolvimento 


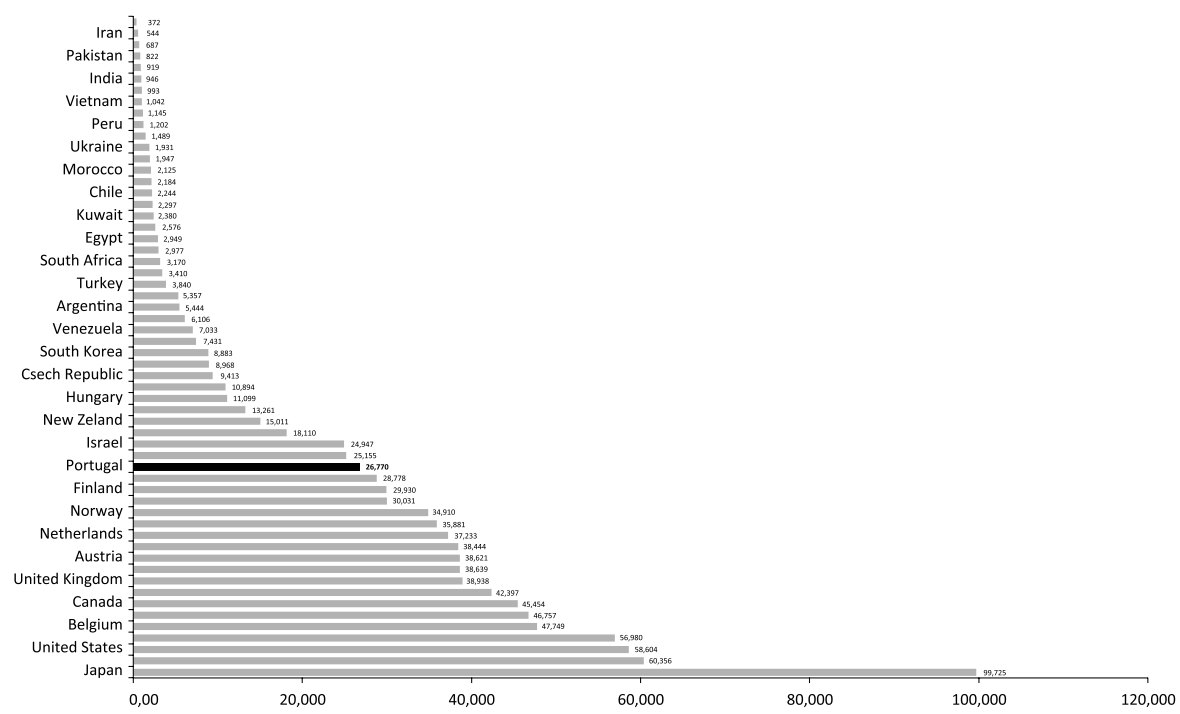

Fig. 3: Comparação da divida soberana per capita entre países

(Fonte: Elaboração própria, com base nos dados primários Bloomberg Visual Data - 2015)

e bem-estar social da comunidade (evitando o correspondente «custo de oportunidade» de não os fazer), para financiar uma reestruturação orgânica e funcional do Estado, tornando-o mais eficaz e eficiente, bem como para acorrer a catástrofes naturais e guerras, entre muito outros. Não é necessariamente sinónimo de «vida fácil».

\section{As várias nuances do endividamento público}

Independentemente das visões que se tenha sobre o endividamento, numa coisa existe unanimidade: quanto menor o volume de dívida, melhor. $\mathrm{Na}$ aparência e, em grande medida, na realidade, a dívida soberana é o problema central do foro orçamental de Portugal. Mas veremos também que não é só nem tanto o volume, mas a natureza e qualidade da dívida que importa atender em especial.

A questão da sustentabilidade da dívida pública é das mais repisadas e debatidas de todo o espetro da ciência económica. Não faltam opiniões e até cálculos para tal, que sucessivamente se vieram a demonstrar pouco sustentados ${ }^{24}$. O limite protagonizado no 
PAeC (60\% do PIB) não pode servir de referência sólida, já que ainda carece de explicação científica credível $^{25}$. Vimos já que essencialmente o crescimento económico e a inflação podem resolver, de forma ativa ou passiva, dívidas soberanas aparentemente insanáveis. Mesmo quando tal não acontece, existe sempre a hipótese extrema de reestruturação da dívida, incluindo os famosos «haircuts», como aconteceu com a austera Alemanha, durante a letargia económica em que mergulhou em 1953, beneficiando de um perdão parcial da dívida do pós-guerra, num montante equivalente a metade do stock, bem como uma redução da taxa de juro e um reescalonamento do plano de pagamento. Só assim conseguiu passar de quase $700 \%$ de endividamento público face ao PIB no início da 2. ${ }^{\text {a }}$ Grande Guerra para menos de $20 \%$ na década de 1970 , ganhando balanço para épocas de maior prosperidade.

Não obstante todas estas considerações, como, de resto, em muitas áreas da economia e finanças públicas, a sustentabilidade da dívida soberana, assenta num jogo de confiança, no qual o credor exige um prémio de risco superior quando esse sentimento baixa em relação ao devedor, sentimento esse não raras vezes de base eminentemente subjetiva ${ }^{26}$.

A dívida portuguesa tem uma particularidade muito importante e que, estranhamente, tem sido obnubilada pelos especialistas na matéria - a sua natureza genética -, o que nos leva para os conceitos de dívida virtuosa, viciosa e duplamente viciosa ${ }^{27}$. Todos sabemos que, mesmo a nível doméstico, nem toda a dívida é igual. Na verdade, uma coisa é uma família endividar-se para investir em habitação ou num terreno para construção ou exploração agrícola, outra é para adquirir o último modelo daquela marca de automóveis de sonho, viagens ou roupa. No primeiro caso, estamos a falar de dívida para investimento, esperando-se que o bem em causa possa vir a gerar retorno económico, quiçá a reproduzir riqueza (dívida virtuosa), enquanto que, neste último, trata-se de endividamento para trazer bem-estar efémero, consumível a curto-prazo sem caráter reprodutivo (dívida viciosa).

Mas pior é contrair dívidas para pagar juros de dívida antiga, situação que, gerando um efeito bola de neve, e se não ocorrer um choque orçamental de qualquer espécie que

No entanto, foram contundente e algo embaraçosamente confrontados com erros de metodologia e de análise por um grupo de jovens economistas da Universidade de Massachusetts Amherst. Uma das críticas refere-se à subestimação da influência da dívida privada na evolução da economia e até da própria dívida pública (efeito transferência dívida privada - dívida pública).

25 No fundo, um valor alinhado com o dos países precursores do Euro - França e Alemanha - à data das conversações que deram origem ao Tratado de Maastricht, evidenciando uma visão umbilical das regras a impor aos restantes.

26 Embora as agências de rating desempenhem um papel facilitador neste capítulo, ao disponibilizar aos seus clientes análises supostamente objetivas versando a capacidade de solvência das diversas entidades.

27 Vide, a este propósito, José Torres, op. citada. 
mude esse estado de coisas, inevitavelmente irá acarretar a insolvência familiar, já que esta não consegue gerar superavits orçamentais estruturalmente compatíveis com as suas necessidades de financiamento. Aqui estamos perante uma divida duplamente viciosa.

No plano macro, a dívida pública torna-se virtuosa quando é utilizada de modo inequívoco para o progresso socioeconómico de um país, nomeadamente para ajudar a cobrir o défice do saldo de capital, em especial quando gerado por investimentos reprodutivos. Mas é à partida viciosa se se destinar a cobrir défices orçamentais correntes, já que aqui apenas se estará a adiar (e a agravar) o problema. Contudo, é preciso dizer que a grande parte da despesa primária do Estado (ou seja, com exclusão dos juros da dívida), seja de pessoal, consumos intermédios e até a de cariz transferencial (como por exemplo as prestações sociais) não são improdutivas, pois destinam-se em última instância, a produzir bem-estar para as populações. Assim é, só a título de exemplo, quando se paga salários de médicos e professores, o consumo de combustível para o patrulhamento policial das ruas ou simplesmente o subsídio de desemprego a um cidadão. O problema é ter que contrair dívida de médio/ longo prazo para o fazer, o que faz emergir um desequilíbrio temporal entre a origem e a aplicação do capital.

Torna-se mais grave ainda quando a dívida é aplicada, mesmo que de forma parcial, no pagamento de encargos com dívida antiga, inclusive em processo de renovação, o que acaba por ser uma derivação dos conhecidos jogos de Ponzi ${ }^{28}$. No fundo, representa a sua eternização - uma espécie de dívida autofágica, que é contraída para pagar os encargos com a anterior, tornando-se cada vez mais volumosa, inerte e naturalmente impagável. Nestes casos a dívida é duplamente viciosa, fazendo normalmente antever o caos financeiro.

Se fizermos um estudo de correlação estatística, verificaremos que $99 \%$ da dívida do Estado português tem estado diretamente ligado à evolução da despesa corrente, incluindo o pagamento de juros de dívida antiga, sendo aquela a grande responsável pela derrocada das contas públicas e em parte pelo mergulho económico português. Reparemos no gráfico seguinte:

28 O termo Jogo de Ponzi é inspirado no esquema dos anos 20 do século $\mathrm{XX}$ da autoria de Charles Ponzi, consistindo numa operação fraudulenta de investimento do tipo esquema em pirâmide que envolve o pagamento de rendimentos anormalmente altos aos investidores atuais à custa do dinheiro pago pelos que chegarem posteriormente. Aparentemente, o Estado pode desenvolver uma operação do tipo «jogo lícito de Ponzi», ao emitir nova dívida para pagar dívida vencida. No entanto, teoricamente, tal só é viável quando a taxa de crescimento real da economia é superior à taxa de juro real da dívida soberana. 


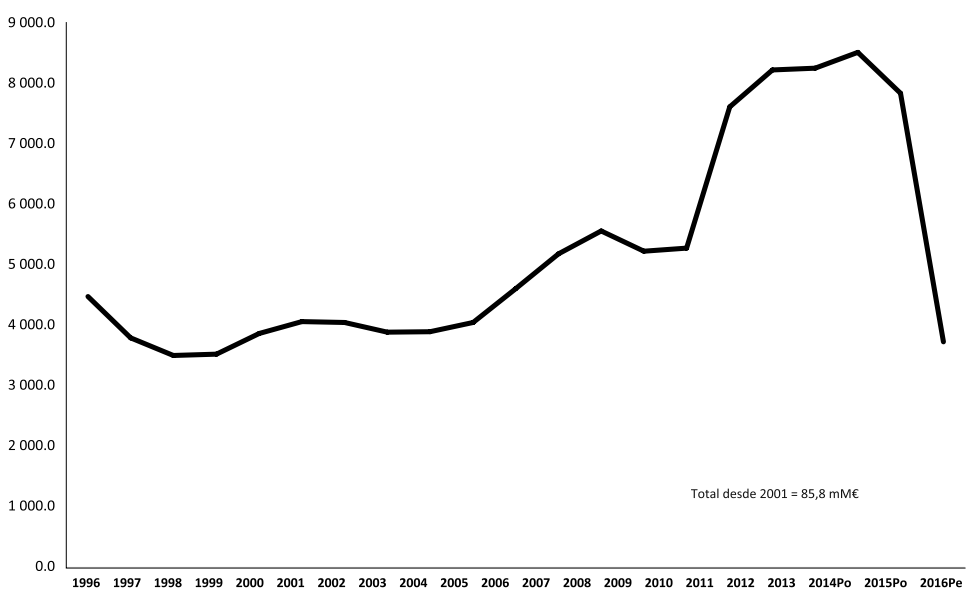

Fig. 4: Volume de divida pública assumida diretamente para pagar juros de dívida pública portuguesa (Fonte: Elaboração própria)

Conforme decorre da sua leitura, desde a entrada na zona euro Portugal contraiu cerca de 85,8 mil milhões de euros de dívida soberana exclusivamente para pagar os encargos com dívida antiga, o que representa $36 \%$ do stock de dívida registado em $2016^{29}$. Este valor astronómico, que decorre da geração de saldos primários sem capacidade de cobertura das despesas com juros ${ }^{30}$, correspondendo a três orçamentos de saúde e educação juntos, expõe o país a uma elevada vulnerabilidade a choques externos com origem no mercado de financiamento público, o qual se tem revelado extremamente nervoso, volátil e desconfiado, em especial no que concerne à dinâmica da nossa dívida pública e aos fundamentais macroeconómicos, em geral.

Deste modo, se atentarmos no quadro seguinte, verificamos que, de facto, tem sido em especial o efeito da acumulação de juros pagos aos credores o fator primordial de agravamento do rácio da dívida pública face à riqueza produzida pelo país, revelando uma preocupante consistência nessa pesada fatura orçamental.

29 O agravamento sensível dos pagamentos de encargos com a dívida soberana a partir de 2010 reflete a dificuldade de financiamento do Estado na sequência da crise de 2008 , que fez disparar a taxa de juro da dívida soberana. $O$ apoio da «troika» - Comissão Europeia, BCE e FMI - nessa altura crítica da nossa história económica recente, apesar dos méritos reconhecidos, não primou por ser especialmente generosa nesse capítulo, já que a taxa de juro implícita rondou os 3,6\%, muito acima dos custos financeiros que a mesma, por sua vez, assumiu junto dos credores.

30 Aliás, muito deles já de si deficitários. 


\begin{tabular}{lccccccc}
\hline & 2010 & 2011 & 2012 & 2013 & 2014 & 2015 & 2016 \\
\hline 1. Stock da dívida bruta (final do período) & 96,2 & 111,4 & 126,2 & 129,0 & 130,6 & 129,0 & 130,4 \\
\hline 2. Variação da dívida (p. p. do PIB) & 12,6 & 15,2 & 14,8 & 2,8 & 1,6 & $-1,6$ & 1,4 \\
\hline 3. Efeito dinâmico & 0,8 & 6,4 & 10,0 & 3,5 & 2,8 & $-0,1$ & 0,5 \\
\hline Efeito juros & 2,9 & 4,3 & 4,9 & 4,9 & 4,9 & 4,6 & 4,2 \\
\hline Efeito do crescimento nominal do PIB & $-2,1$ & 2,1 & 5,1 & $-1,4$ & $-2,1$ & $-4,7$ & $-3,8$ \\
\hline 4. Efeito do Saldo Primário & 8,2 & 3,1 & 0,8 & 0,0 & 2,3 & $-0,2$ & $-2,2$ \\
\hline 5. Outros & 3,5 & 5,8 & 4,0 & $-0,6$ & $-3,5$ & $-1,3$ & 3,1 \\
\hline
\end{tabular}

Fig. 5: Dinâmica da divida pública portuguesa

(Fonte: Elaboração própria, com base nos dados primários do MF)

O peso dos juros faz-se sentir cada vez mais nos orçamentos nacionais, pressionando contínua e crescentemente a despesa corrente, a qual continua a suplantar a receita homóloga (corrente), criando défices indutores de dívida viciosa e duplamente viciosa, como vimos. Este é um dos desafios atuais da gestão das contas públicas da atualidade, já que nos mais de 40 anos de democracia raramente cumprimos a regra considerada por Keynes como a pedra angular neste domínio: existência de superavits correntes para financiar os défices virtuosos do saldo de capital ou, não sendo isso possível, emissão controlada de dívida para esse efeito. No meio deste nevoeiro ideológico, nada como rebuscar os clássicos.

Repare-se no gráfico seguinte:

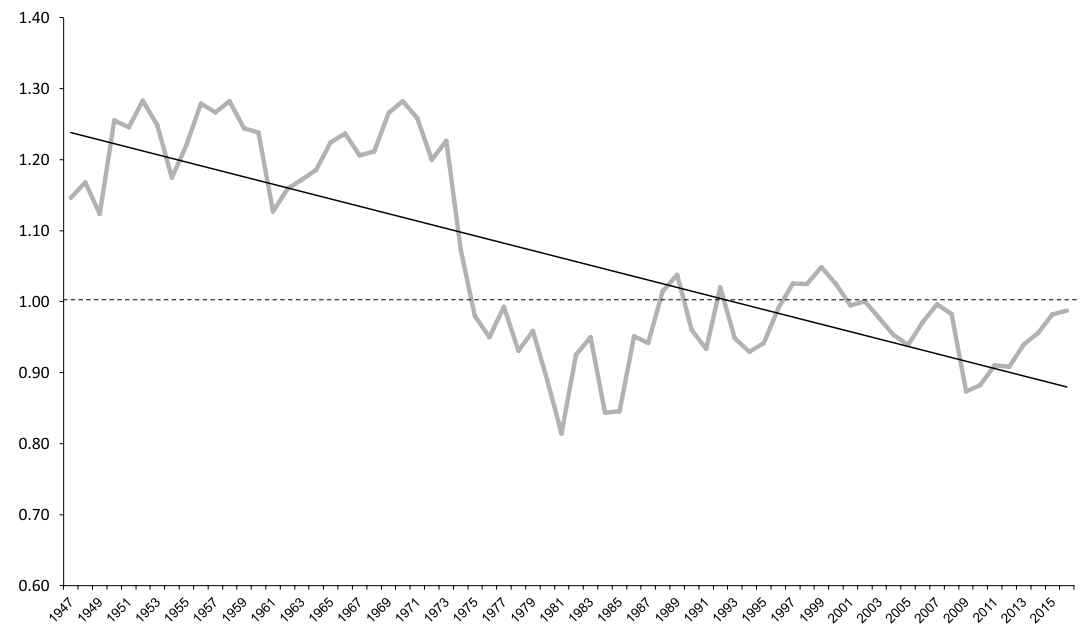

Fig. 6: Evolução do grau de cobertura das despesas correntes pelas receitas correntes 
Como se pode verificar, depois de uma "época dourada" no que toca à observância da regra de ouro keynesiana que coincidiu com a ditadura de Salazar ${ }^{31}$, na era democrática rareiam as situações de controlo do défice corrente, levando à contração permanente de dívida viciosa, quando não duplamente viciosa. Aliás, foi precisamente durante o período em que Portugal recebe assistência financeira externa $(1979,1983$ e 2011) onde o défice corrente se revelou mais descontrolado, o que indicia a importância efetiva desse exercício de rigor orçamental.

A realidade mais recente, apesar de ainda insatisfatória neste domínio, apresenta tendência de melhoria, embora, há que dizê-lo, se levantem algumas dúvidas sobre a sua sustentabilidade, tais as fontes de pressão existentes. E entre elas estão os juros da dívida pública, pese embora o esforço de reestruturação da dívida levados eficazmente pelo IGCP, substituindo dívida mais cara por outra mais suave e preferencialmente com períodos mais longos, aproveitando uma conjuntura favorável para tal - muito por mérito do BCE -, de forma a aliviar as necessidades futuras de financiamento. Para além disso, há que esperar para ver os efeitos da reversão de algumas das últimas medidas conjunturais de pura austeridade, como o descongelamento das progressões na Administração Pública e a abolição total da sobretaxa de IRS.

Mas existem outros, de teor mais estrutural, em sede de despesa corrente primária, como os encargos crescentes das pensões face ao envelhecimento populacional - uma autêntica «bomba relógio orçamental» -, obrigando, mais tarde ou mais cedo, a tributar de forma mais agressiva as pensões em pagamento mais elevadas, a par das alterações de cariz restritivo no regime de aposentação dos atuais contribuintes, que têm vindo a ser sucessivamente implementadas. Também a questão dos gastos tendencialmente crescentes na saúde, fruto do avanço tecnológico, do aumento da esperança de vida e da atividade permanente de lobbying das grandes empresas do setor impõem desafios aos Governos democráticos, nomeadamente no plano ético-moral ${ }^{32}$. Por último, claro, a eternamente adiada reestruturação orgânico-funcional do Estado, no sentido de uma racionalização vertical e horizontal (fusão, «downgrading» e «downsizing»), talvez a forma mais eficaz e efetiva de reduzir a despesa corrente primária, bem como a que, teoricamente, apresentará menor potencial de nocividade para a Economia e de convulsão social.

31 Embora existam fundadas dúvidas quanto ao rigor e fidelidade das contas públicas dessa longa noite da História de Portugal. Mas, seja como for, um exercício de boa contabilidade não significa idêntico sucesso na governação, mesmo no plano económico. Na verdade, o custo de oportunidade dessa opção cega pelo rigor ortodoxo do controlo dos défices e da dívida, mesmo com espaço de endividamento, foi bem sentido pela generalidade dos portugueses, ao nível da pobreza e do acesso à educação, saúde e cultura.

32 Onde talvez a discussão mais sensível passe pela gestão adequada do eterno equilíbrio entre o prolongamento da vida em doentes com baixa esperança de vida e o investimento em profilaxia. Ou até onde deve ir o esforço na deteção precoce de possíveis - mesmo que pouco prováveis - doenças graves num futuro mais ou menos distante da vida de cada ser humano. 
Ora, com todo este incontido avolumar de dívida pública geneticamente viciosa, não se repercutindo em investimento público reprodutivo que gere crescimento económico, e sem a «boleia» da inflação, abre-se de facto espaço, mais tarde ou mais cedo, a novas políticas tendencialmente austeritárias, não tanto para mitigar o seu stock de forma direta - os efeitos são pouco relevantes neste capítulo - mas essencialmente para tranquilizar os «mercados», sempre receosos que a situação descambe ao ponto dos seus créditos financeiros poderem vir a ser prejudicados em termos de rentabilização efetiva.

\section{A dívida pública externa}

Sabe-se que o endividamento externo, como um todo, acarreta especiais vulnerabilidades e consequências económicas e financeiras. Contudo, a questão particular da dívida pública externa, em especial quando do tipo negociável, não é menos importante.

Ao contrário da dívida interna como um todo, que não gera ónus para as gerações futuras, já que se trata apenas de um fluxo financeiro interno (o dinheiro passa de umas mãos para outras) - exceto em situações especiais e raras do ponto de vista macroeconómico em que a compra de dívida pública pela sociedade civil nacional implica a privação pela mesma de bens relevantes de consumo ${ }^{33}$-, a dívida pública externa implica forçosamente ónus para as gerações futuras, na medida em que a amortização e o serviço da dívida serão por elas também suportados, para mais com um exfluxo monetário para o exterior sob a forma de juros.

Por outro lado, existem outros aspetos não menos importantes a considerar associados à dívida soberana quando detida por entidades externas, especialmente no quadro de orientações superiores de índole geopolítica e geoeconómica. Na verdade, quando dependente do financiamento de entidades externas, qualquer país fica de algum modo subordinado às suas estratégias particulares - não raras vezes em alinhamento estreito com potências estrangeiras - e frequentemente aos seus humores e excentricidades conjunturais. A perda de controlo e de soberania é evidente ${ }^{34}$. Como disse um dia uma reputada economista e ex-governante portuguesa, «quem empresta, manda!».

Para além disso, importa ter igualmente em conta o maior ou menor grau de negociabilidade da dívida pública, ou seja, a sua composição específica - detenção de instrumentos de maior ou menor liquidez, de cariz mais conservador ou especulativo. O quadro seguinte

33 Embora agrave fenómenos de desigualdade social, já que os detentores de dívida pública são muito menos e em média mais abastados do que a generalidade dos contribuintes.

34 Como recentemente pudemos constatar com a entrada em cena da troika e, na atualidade, na relação com o BCE, um dos principais detentores de Obrigações de Tesouro nacionais. 
(fig. 7) ilustra a evolução da composição da dívida pública direta portuguesa, no que toca ao seu grau de negociabilidade.

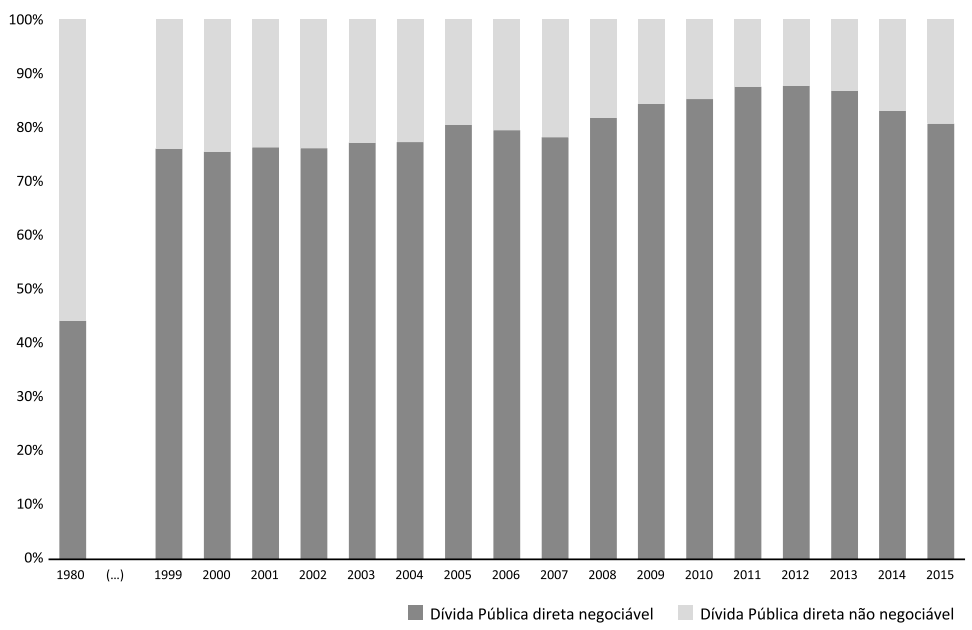

Fig. 7: Evolução da composição genérica da dívida pública nacional, excluindo o PAEF (Fonte: Elaboração própria, com base nos dados primários do IGCP)

Como se pode inferir facilmente do mesmo, desde 1980, ano que a parcela de dívida não negociável ${ }^{35}$ foi mais elevada, o peso da dívida negociável ${ }^{36}$ tem vindo a aumentar de forma sistemática até atingir em 2011 e 2012 o valor recorde de 88\% do total, vindo desde então a diminuir, não tanto por opção estratégica, mas essencialmente por força da substituição das operações normais de financiamento nos mercados pelo Programa de Assistência e Estabilização Financeira (PAEF), acordado em 2011 entre o Estado português e a troika. Essa tendência tinha como efeito a crescente sujeição das necessidades de financiamento da Administração Pública aos humores e sensibilidades dos mercados financeiros e de lógicas puramente especulativas, mesmo de entidades residentes (ex: sociedades financeiras), ditados inevitavelmente pelas agências de rating. $E$ isso normalmente não é bom. Claro que a adesão à zona euro, com a ilusão que trouxe de que as taxas de juro da dívida pública portuguesa estariam sempre ao nível das alemãs, como de resto aconteceu até 2008 , esmo-

35 Dirigida a investidores particulares de perfil mais conservador, que buscam rentabilidades interessantes sem grande risco, como os Certificados de Aforro.

36 Dívida normalmente dirigida a investidores institucionais e comercializada no mercado primário, maioritariamente sob a forma de Bilhetes do Tesouro e Obrigações do Tesouro. 
receu naturalmente a prudente preocupação de lhe conferir uma estrutura mais estável e previsível, para evitar embates externos.

Mas para além desta abordagem à dívida pública, urge ainda decompô-la quanto à origem do financiamento da mesma (interna e externa) até ao ano de charneira (2011), altura em que se começa a fazer sentir a crise financeira global e em que entra em cena a troika, como decorre da fig. 8.

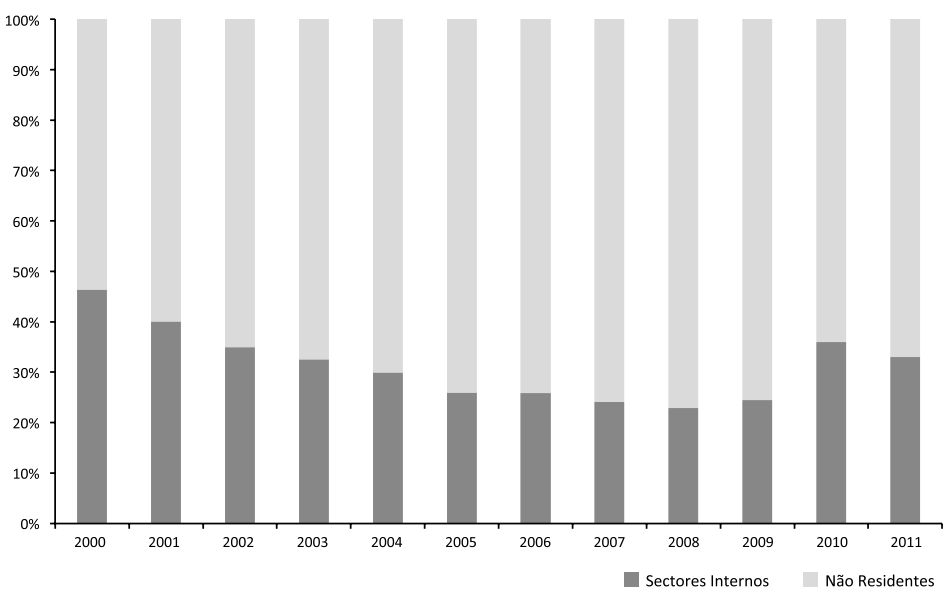

Fig. 8: Evolução da estrutura de Dívida Pública nacional segundo o tipo de detentor no período 2000-2011 (Fonte: Elaboração própria, com base nos dados primários do BdP)

Como resulta da sua leitura imediata, até 2008 a dívida pública nacional esteve de forma crescente nas mãos de entidades não residentes no país, em paralelo com a tendencial diminuição do rendimento disponível das entidades nacionais (particulares e empresas) e da liquidez das instituições financeiras que por aqui operam. A partir desse ano houve uma ligeira inversão da tendência, já que, para além da operação de financiamento da troika, os bancos nacionais aproveitaram o financiamento a baixo custo do BCE para adquirir lotes maciços de dívida pública portuguesa, o que lhes permitiu obter uma rendibilidade apreciável, embora sem dispensar um certo grau de risco ${ }^{37}$. 
De acordo com os dados mais recentes ${ }^{38}$, o maior credor de dívida pública portuguesa em 2015 continuam a ser entidades externas, embora com menor intensidade, com a troika à cabeça (36,7\% do total da dívida portuguesa), representando os restantes investidores não residentes $29,9 \%$. Os residentes particulares aumentaram em $28 \%$ a sua carteira de títulos de dívida pública face a 2010, maioritariamente através de Certificados de Aforro (CA) e Certificados do Tesouro (CT), representando agora 7,4\% da dívida pública portuguesa. Por outro lado, o setor financeiro residente diminuiu a sua exposição para $25 \%$, representando agora menos 4,3 p.p. do que em 2010.

É uma situação que, a manter-se em todos os seus contornos - há que ter em atenção em especial a forma de substituição da dívida à troika à medida que ela vai chegando ao fim, via efeito rolamento do stock -, pode anunciar uma tendência de maior previsibilidade e estabilidade das taxas de juro nacionais, tornando a dívida pública menos vulnerável a choques externos, ao mesmo tempo que não acarreta uma sangria tão grande de riqueza para o estrangeiro ${ }^{39}$.

A figura 9 (infra) ilustra genericamente os quatro quadrantes possíveis de posicionamento da dívida pública quanto à sua estrutura e composição - origem geográfica do financiamento e grau de negociabilidade do instrumento de dívida em concreto. Durante o período democrático, Portugal começou cómoda e tranquilamente pelo quadrante virtuoso (C), ainda no rescaldo de uma ditadura conservadora e nacionalista, com fraca abertura financeira ao resto do mundo. O financiamento da dívida pública, ainda em níveis muito baixos, assentava em grande parte na componente interna não negociável, especialmente CA. De acordo com as estatísticas do $\mathrm{IGCP}^{40}$, ainda em 1980 a componente interna não negociável atingia 45,4\% da dívida pública total, o que conferia, de facto, à execução orçamental e à gestão financeira do Estado uma elevada previsibilidade e estabilidade, para além de evitar que grande parte das remunerações dos empréstimos fluíssem para o exterior.

38 Relatório Anual da Comissão de Finanças Públicas (2015).

39 Um documento do EUROSTAT, disponível em «http://ec.europa.eu/eurostat/documents/2995521/8068939/220062017-AP-EN.pdf», refere que Portugal é dos países que tem mais dívida na posse de não residentes - quase $60 \%$, sendo que mais de $30 \%$ de toda a dívida está nas mãos de entidades residentes mas de cariz financeiro, naturalmente com maior propensão para o seu tratamento de forma especulativa.

40 Disponíveis em www.igcp.pt. 


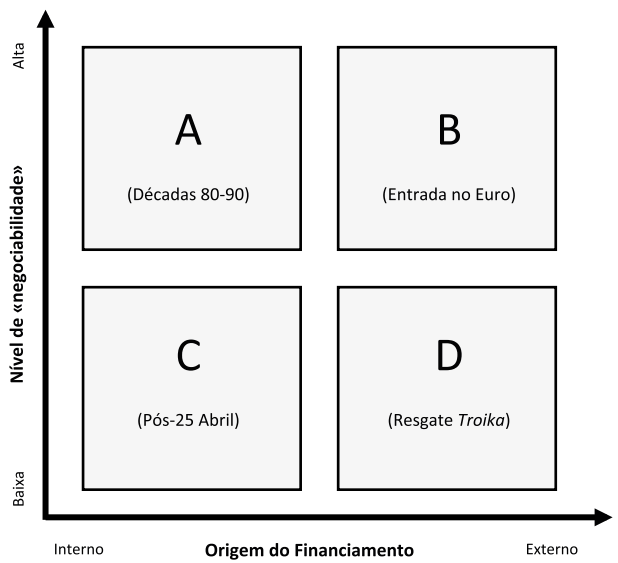

Fig. 9: Posicionamentos estruturais da dívida pública de um país

(Fonte: Elaboração própria)

Mais tarde, em meados da década de 80 e 90, com o aumento do rendimento das famílias e do capital disponível entre as empresas e bancos ${ }^{41}$, para além da modernização do mercado de dívida pública no sentido de aumentar a liquidez e a atratibilidade dos produtos e a facilidade de comercialização, o Estado acentuou a aposta em instrumentos de dívida de cariz mais transacionável, maioritariamente Obrigações do Tesouro (OT). Assim, em 1999, cerca de $93 \%$ da dívida pública era detida por investidores residentes, a maior parte deles já de cariz institucional, sendo que $70 \%$ da mesma tinha um cariz negociável (Quadrante A) ${ }^{42}$.

Nas imediações e em plena era de vigência do euro, no esplendor da globalização financeira, a tendência de apostar em títulos de dívida pública de elevado grau de negociabilidade acentuou-se, essencialmente através de emissões sindicadas e leilões. Para além disso, com o conforto de uma moeda forte e estável, como o euro, começaram a entrar de forma massiva investidores internacionais (a dívida deslocalizou-se para o quadrante B), muitos deles de cariz profissional (como os grandes fundos de investimento), levando a que, no fatídico ano de 2008 , as OT já representavam $69 \%$ dos instrumentos de dívida pública - com os instrumentos não negociáveis a contribuir negativamente para o financiamento da República

41 Embora, tenha coincidido também com uma sensível redução da taxa de poupança das empresas e, em especial, das famílias. Segundo Fernando Alexandre et al. (op. citada), referindo-se a um estudo com Miguel Portela, a taxa de poupança das famílias desceu de $20 \%$ em meados da década de 80 para $10 \%$ em meados da década seguinte.

42 Os EUA, apesar de serem largamente os maiores devedores do mundo, apenas cerca de um terço dessa dívida pertence a estrangeiros. 
-, sendo que 77,1\% do total da dívida pública estava nas mãos de não residentes, um dos valores mais altos de sempre, senão mesmo o mais alto. Finalmente, com a intervenção da troika, a estrutura da dívida pública posicionou-se no quadrante $\mathrm{D}$ - isto se considerarmos a dívida contraída àquela entidade como não negociável -, embora a componente negociável, pela sua dimensão absoluta, continue a ser uma fonte de nervosismo para os gestores do orçamento português. Qualquer espirro interno ou externo assusta os mercados, provocando instabilidade no planeamento e na execução orçamental. Basta ver que a componente de juros da dívida pública, a rondar os 8,2 mil milhões de euros, já representa algo como $11 \%$ do total da receita corrente e mais do dobro do investimento efetuado nesse ano.

Obviamente que o ideal para uma nação é manter-se no quadrante virtuoso (C). Para alguns ainda pode ser possível mas, face à dimensão da dívida pública, necessidades anuais de financiamento da Administração Pública e aos níveis de poupança doméstica, tal seria impossível. Resta-nos políticas públicas que paulatinamente mitiguem a componente transacionável e, em especial, externa da dívida.

No entanto, algumas decisões políticas num passado recente não foram muito felizes em termos de mobilização de particulares para aquisição de dívida soberana, no fundo aqueles que dão maiores garantias de estabilidade e de fidelidade. Por exemplo, a alteração das condições remuneratórias dos CA - uma marca histórica de elevada notoriedade e reconhecida confiança entre os portugueses -, para a sua quase desvalorização, desviou muitos fundos para aplicações alternativas, como depósitos bancários.

Contudo, primeiro com o aparecimento dos Certificados de Tesouro (CT), a oferta de dívida soberana tornou-se muito mais atrativa em termos remuneratórios para os pequenos e médios investidores, que viram aí uma oportunidade de diversificar e, em especial, rentabilizar as suas poupanças face à anemia das aplicações sucedâneas de baixo risco. No entanto, o lançamento deste instrumento de dívida pública foi sempre algo tímido, parecendo mostrar mesmo algum receio que tal viesse a afetar os resultados operacionais das entidades bancárias face às alternativas por elas oferecidas ao investidor particular conservador, em especial os clássicos depósitos à ordem e a prazo, pauperrimamente remunerados. Sem se perceber bem porquê, em setembro de 2012 foram suspensos os novos lançamentos de CT.

Mais recentemente, numa jogada de alguma ousadia face a um certo «mainstream» de respeitinho pela banca, foram lançadas as chamadas Obrigações do Tesouro de Rendimento Variável (OTRV), valores mobiliários representativos de empréstimos de médio e longo prazo da República Portuguesa, criados com o propósito de impulsionar o mercado de dívida pública através da diversificação dos instrumentos de dívida pública e dos canais de distribuição disponibilizados aos investidores e do alargamento da base de investidores 
em dívida soberana. Apesar de, na prática, ser tecnicamente classificada como dívida negociável, especialmente dirigida a investidores particulares com perfil de fraca tolerância ao risco ou até conservador, introduzem uma maior estabilidade e previsibilidade à evolução da estrutura e do custo da dívida pública a médio e longo prazo, rivalizando de forma direta com instrumentos de dívida genuinamente não negociável (CA e CT), mas também com a oferta clássica das entidades bancárias para as poupanças das famílias e empresas, que com elas também lucram sob a forma de comissões de vendas aos balcões.

O seu sucesso prova que os portugueses têm confiança na dívida do seu país, pelo que será seguramente uma aposta a manter e, se possível, a intensificar-se, até porque, segundo os últimos dados recolhidos, só em depósitos bancários existem mais de 140 mil milhões de euros em Portugal ${ }^{43}$. A ideia a seguir passa por transferir necessidades de financiamento satisfeitas junto dos investidores institucionais, mesmo que residentes em território nacional, para o público em geral ${ }^{44}$. Mas para que tal resulte as taxas de remuneração dos instrumentos de dívida pública dirigidos a particulares residentes têm de ser atrativas e assumir-se como uma alternativa credível face às demais, mesmo que tal signifique afrontar o poder da banca e dos poderosos fundos de investimento internacionais.

A este propósito, vale a pena trazer aqui à colação a teoria da democratização da dívida, explanada por José Teixeira45, com base na doutrina de De Viti de Marco ${ }^{46}$. Segundo a mesma, no seu conceito purista, numa sociedade inicialmente muito desigual, quando o Estado emitia dívida, dirigia-se a quem detém relativamente mais capital disponível, normalmente as classes mais abastadas. Ora, para amortizar essa dívida, o Estado tem sempre de lançar impostos dirigidos não só àqueles, mas também aos restantes contribuintes, pobres e remediados, o que significa que os «capitalistas» são quem mais acaba por lucrar na consolidação das contas - o que pagam de impostos é mitigado com o recebimento de juros, enquanto que os restantes só pagam impostos.

No entanto, com o crescimento do rendimento disponível na chamada classe média, se o Estado conseguir atrair as suas poupanças em títulos de dívida pública, esta situação altera-se substancialmente, podendo esta também beneficiar de juros que amenizam o pagamento futuro de impostos para financiar a dívida pública emitida, equilibrando o

43 De acordo com os resultados do $2 .{ }^{\circ}$ Inquérito à Literacia Financeira da População, promovido pela Autoridade de Supervisão de Seguros e Fundos de Pensões, BdP e CMVM (2016), 15\% dos portugueses guardam o dinheiro em casa, sendo que apenas $60 \%$ aplicam em depósitos bancários.

44 Se bem que o Banco de Portugal, por via do famoso programa de Quantitative Easing do BCE, se assume cada vez mais como um dos principais detentores de dívida soberana portuguesa, facto que, para além das questões de estabilidade e de retenção interna de riqueza já invocadas, tem um aspeto adicional importante: o potencial aumento dos dividendos a favor do Estado, que tendencialmente anulam os encargos com a dívida por ele detida. 
esforço e levando à sua amortização «democrática», no sentido de equitativa, deixando de ser encargo de apenas alguns estratos sociais mais desfavorecidos. Assim, até neste desiderato de aumentar a parcela da dívida pública interna não negociável, para além das considerações que fizemos em termos de soberania, liberdade decisória e manutenção da riqueza em solo nacional, prosseguem-se objetivos de justiça e igualdade sociais.

Atente-se que, em teoria, se o investidor particular fosse um ser estritamente racional e totalmente informado, a remuneração de uma aplicação em dívida pública deveria, em termos líquidos, no mínimo ser igual à taxa de juro praticada no mercado primário deduzida do efeito de evitamento dos impostos que teria de pagar caso o Estado ali se financiasse. Exemplificando: suponhamos que o Estado consegue colocar no mercado primário dívida pública a $3,5 \%$ e que a carga fiscal que impõe aos seus contribuintes para garantir saldo orçamental total nulo é de $40 \%$. Neste caso, o tal idílico investidor, antecipando o que iria pagar de impostos para cobrir os encargos dessa nova dívida a emitir, exigiria no mínimo uma remuneração depois de impostos de $2,1 \%{ }^{47}$ para patrioticamente adquirir títulos alternativos de dívida pública. E é também esse, no plano estritamente da racionalidade financeira, o limite de remuneração líquida que o Estado deve poder oferecer aos investidores particulares nas condições aqui simuladas.

Claro que com isto não queremos dizer que se pode e deve descurar a aquisição de dívida pública nos mercados financeiros, dominados por investidores institucionais. Estes serão sempre importantes, já que para a satisfação integral das imensas necessidades de financiamento da Administração Pública não chegam as poupanças dos particulares, longe disso. E, para tal, muito ainda pode ser feito, à semelhança da experiência italiana: aumentar a atratibilidade do mercado de dívida pública nacional, estimulando a procura e baixando assim a taxa de juro associada, através, por exemplo, da dinamização do mercado de derivados e futuros a ela associados. Na verdade, embora por vezes tal seja obnubilado, a questão da volatilidade e da liquidez, para além da confiança na solvabilidade da dívida, também são fatores de ponderação para os investidores profissionais.

Resta dizer sobre isto que ainda existe mais um importante elemento de configuração do stock da dívida soberana: a sua composição em moeda estrangeira. Se bem que não seja tão importante para países membros da UE, pois possuem uma moeda comum de grande credibilidade e forte no panorama internacional, esta questão pode assumir uma grande relevância noutros países com moedas frágeis e com elevada exposição a dívida com moeda estrangeira, fazendo adicionalmente emergir um risco cambial. Portugal apresentava em 
finais de 2016 uma dívida direta do Estado em moeda não euro somente na ordem dos 1,8\% do total ${ }^{48}$, o que relega este aspeto para plano secundário.

\section{Será adequado o controlo interno e externo das contas públicas?}

Não obstante a obrigatoriedade legal e moral de assegurar disciplina financeira e orçamental num espaço com moeda única, não nos parece fazer muito sentido o famoso teto de $3 \%$ de défice global face ao PIB, imposto pelas regras europeias. Podemos começar, de resto, pela explicação original do seu cálculo pelo seu criador, Guy Abeille, ex-conselheiro económico do antigo presidente francês, François Mitterrand, numa entrevista ao jornal «Le Parisien» (edição de 28SET2012). Segundo as suas palavras, nunca desmentidas, tendo em conta o pouco tempo que o presidente lhe deu para essa espinhosa tarefa - este estava a poucas horas de viajar de avião -, basicamente socorreu-se de alguma intuição, bom senso e até de alguma inspiração divina, pois era numericamente equivalente, disse Abeille, com a «santíssima trindade»! Na verdade, aquele histórico governante francês pretendia colocar um limite psicológico fácil de reter aos ensejos despesistas dos seus ministros, tendo então sacralizado esse valor como travão. Mais tarde, como sabemos, foi acolhido no seio das negociações de Maastricht.

Mesmo no plano material, a opção pelo saldo global como referência de controlo orçamental tem diversas condicionantes. Na verdade, uma nação pode ter o seu défice global equilibrado, mas apresentar um desequilíbrio intrínseco, como, por exemplo, ter o saldo corrente cronicamente deficitário, colmatado por um excedente de capital que, de forma contraproducente, vai conseguindo obter. Por exemplo, estar a financiar a insustentabilidade da sua segurança social com receitas provenientes de privatizações, solução que apenas é válida enquanto houver «joias» para vender. É como se uma família financiasse roupa com venda de património. A prazo, as fragilidades dessa opção irão inevitavelmente emergir, obrigando-a a mudar de vida ou abrir insolvência.

Existe atualmente uma certa tendência para empolar em demasia o chamado saldo primário, isto é, o saldo global expurgado das despesas com encargos da dívida pública. Fala-se mesmo na obrigação de criar saldos primários excedentários como única forma de pagar a dívida soberana. Por tudo o que foi dito atrás, somos obrigados a discordar em boa parte. Aliás, este indicador, que tem inequivocamente algumas virtuosidades, pois evidencia e submete a escrutínio a globalidade das opções de governação financeira diretamente imputáveis aos decisores, sofre dos mesmos problemas que o saldo global, já que permite ocul- 
tar eventuais desequilíbrios na consolidação entre saldos correntes e de capital. Mais, por ignorar os juros da dívida pública, podemos ter saldos primários excedentários, mas não os conseguir absorver com a totalidade das receitas cobradas, obrigando assim o país a contrair dívida para pagar juros de dívida - a tal dívida duplamente viciosa.

Na sequência da crise financeira de 2008, a UE introduziu, através do TO, um limite mais criterioso de controlo do défice orçamental, ao excluir as medidas extraordinárias e temporais e ao depurar os efeitos do ciclo económico - o chamado saldo estrutural -, segundo o qual o correspondente défice não deverá ultrapassar 0,5\% do PIB. No entanto, sendo sem dúvida uma tentativa bem-intencionada e, de certa forma, bem conseguida para obtenção de um retrato mais fiel das opções de política orçamental controladas pelos estados-membros e poder assim responsabilizá-los de forma mais apropriada, peca novamente por não dar tratamento diferenciado às contas corrente e de capital. Para além disso, o seu apuramento reveste uma significativa complexidade e alguma discricionariedade, o que nunca é bom nestes processos.

Seja como for, pouco há a dizer no plano teleológico quanto a estas imposições comunitárias, independentemente da maior ou menor credibilidade da fixação dos valores "mágicos" de $0,5 \%, 3 \%$ e $60 \%$ do PIB, se bem que, no plano metodológico, deveria haver uma abordagem flexível em função do estádio de desenvolvimento socioeconómico de cada país. Se assim já acontece em algumas decisões importantes da UE, como a atribuição de fundos estruturais, não se vislumbra que isso não pudesse acontecer para a fixação de limites ao saldo orçamental e em especial à dívida pública, o que provocaria um crescimento mais harmonioso do bloco económico europeu. Isto não invalida que, como vimos, em nome de princípios de coerência doutrinária e de rigor, pudesse existir uma imposição comunitária de âmbito universal no sentido de manter o saldo corrente em valores nulos ou superavitários, o que imporia uma disciplina acrescida a países por tradição menos focados nesse desiderato, como Portugal.

A nível interno, também a Constituição da República Portuguesa (CRP) estabelece alguns parâmetros de controlo formal do próprio processo de elaboração orçamental, que assim ganham uma força legislativa suplementar. Nesta matéria podemos dizer que exerce dois tipos de controlo: um genérico, visando assegurar a observância de princípios essenciais de um Estado de Direito, alguns deles recorrentemente invocados em sede de fiscalização preventiva e sucessiva da constitucionalidade dos orçamentos (ex: princípios da universalidade, proporcionalidade e da igualdade); e um específico, versando sobre regras basilares inerentes ao processo de conceção e aprovação do orçamento de Estado.

Em tempos como os atuais, com a discussão da constitucionalidade dos orçamentos a adquirir uma especial centralidade no debate político, nomeadamente a sua adequação 
aos tais princípios gerais no âmbito do controlo genérico, não deixa de ser curioso que uma das regras inclusas no n. ${ }^{\circ} 4$ do art. $^{\circ} 105{ }^{\circ}$ da CRP - o equilíbrio orçamental no plano formal - praticamente nunca foi respeitada desde a Revolução dos Cravos, pelo que, numa interpretação literal e rígida da norma, todos esses orçamentos seriam à partida inconstitucionais, como algumas individualidades no meio empresarial e académico vieram lembrar. $\mathrm{Na}$ verdade, uma leitura rígida poderia levar-nos a pensar que o legislador teve uma deriva da mais pura ortodoxia liberal, decalcado do pensamento financeiro clássico, vigente no Estado Novo. No entanto, numa interpretação sistemática, resulta de forma mais ou menos explícita a admissão natural e lógica das chamadas receitas creditícias. Seja como for, no seu todo, resulta numa formulação de cariz meramente formal, pouco exigente e até algo improfícua.

A Lei de Enquadramento Orçamental (LEO), na sua formulação atual ${ }^{49}$, opta por excluir o chamado Princípio do Equilíbrio anteriormente contemplada na sua anterior versão ${ }^{50}$, assente num critério clássico definido de duas formas diferentes: por um lado, impondo aos serviços integrados o equilíbrio ao nível do saldo primário, o que permitia, no fundo, contrair empréstimos para amortizar dívida antiga e/ou os respetivos encargos, que é o mesmo que dizer dívida duplamente viciosa; pelo outro, no que respeita aos Fundos e Serviços Autónomos e à Segurança Social, o equilíbrio radica no saldo global, legitimando apenas a contração de empréstimos para efetuar amortizações ou reembolsos de outros já assumidos.

Em substituição desse antigo Principio do Equilíbrio, a LEO introduz outros preceitos mais prescritivos, uniformes e, de certo modo, exigentes, replicando o que já se encontra nos tratados europeus sobre a matéria, nomeadamente o PaEC e o TO. Em concreto, o seu artigo 9. ${ }^{\circ}$ dedica-se a estabelecer o chamado Princípio da Sustentabilidade das Finanças Públicas, segundo o qual as entidades que constituem o setor das administrações públicas «devem assegurar capacidade de financiar todos os compromissos, assumidos ou a assumir, com respeito pela regra de saldo orçamental estrutural e da divida pública, conforme estabelecido na presente lei».

Nos artigos $20 .^{\circ}$ e seguintes, a LEO vem definir de forma objetiva e numérica os limites considerados de sustentabilidade, já anteriormente aludidos, havendo uma preocupação acrescida em gerir os efeitos e as medidas contracíclicas. Para além disso, enuncia as diversas aplicações dos excedentes e a correção dos desvios orçamentais ao longo do tempo. Curiosamente, não faz alusão à sacrossanta regra do $3 \%$ de défice global sobre o PIB, optando por privilegiar a regra do saldo estrutural, sem, contudo, deixar de exigir 
saldos globais nulos ou excedentários aos diversos subsetores da Administração Central, incluindo a Segurança Social.

\section{Conclusão}

A dívida pública portuguesa cresceu nos últimos anos a um ritmo galopante, apesar de ter partido de uma situação aparentemente confortável na década de 1980 . Tal comportamento foi extensível ao setor privado, que também viu os seus índices de endividamento subir a um nível incompatível com um salutar e regular crescimento económico, também por força da diminuição drástica dos encargos associados. No entanto, a eterna questão da sustentabilidade da dívida acaba por ser o centro de uma discussão inútil, pois está por demonstrar um indicador credível que lhe sirva de métrica. A mesma depende da perceção dos atuais e potenciais investidores quanto à probabilidade de verem o seu capital devolvido pelos Estados, juntamente com a remuneração que lhe está associada. E isso tem muito de subjetivo, de emotivo e até por vezes de irracional, dados os habituais comportamentos de «manada» típicos dos mercados financeiros.

A dívida pública, independentemente do seu nível, pode ser mitigada por diversas formas. O crescimento económico representa a modalidade mais salutar, mas também é a mais difícil. A inflação dá uma ajuda «grátis», mas tem diversas externalidades negativas que podem pôr em causa o bem-estar socioeconómico de um país. Embora hodiernamente defendida pela doutrina reinante, as políticas de austeridade credibilizam a governação perante os credores, mas historicamente apresentam resultados muito discutíveis no que toca ao efetivo abatimento da dívida pública - podem até ter efeitos contrários -, sendo que, seguramente, fragilizam as nações noutros domínios, quando são empurradas a alienar ativos, por vezes estratégicos, em condições pouco vantajosas e apressadas, a cortar investimento e a mitigar a sua despesa de cariz social.

Seja como for, como procurámos demonstrar, contrair dívida não é sempre um exercício de necessidade extrema ou até de leviandade gestionária. Pode decorrer de uma governação atenta, justa e inteligente, pois pode até ser contraída quando não necessária no plano meramente contabilístico e financeiro, com a finalidade, entre outras, de prossecução de princípios de equidade intergeracional. No entanto, há que avaliar a natureza genética da dívida. Quando se destina a cobrir défices de capital provenientes da assunção de investimentos públicos reprodutivos, ela assume um figurino virtuoso, saudável, pois visa, em última instância, obter retorno económico num futuro mais ou menos próximo. Mas quando apenas se destina a suprir necessidades de financiamento de défices correntes ela assume geneticamente uma natureza viciosa. Agrava-se, quando é utilizada para pagar 
juros de dividas antigas, tornando-se duplamente viciosa. Tal facto, infelizmente, tem sido a prática em Portugal, onde, por exemplo, só nos últimos 16 anos, mais de um terço da nova dívida pública se destinou a pagar encargos da anterior.

Este percurso nocivo e, de certa forma, discreto e silencioso das contas públicas portuguesas, tal como de outros países europeus, não tem sido seriamente enfrentado pela UE, tão obcecada que está com parâmetros dogmáticos de controlo das contas nacionais de cariz pouco científico e de eficácia duvidosa, como os famosos limites para o défice e dívida pública face ao PIB. Nem sequer por via dos vários mecanismos de controlo financeiro a nível interno, por tradição pouco exigentes neste capítulo e acriticamente obedientes às receitas europeias. É uma questão cultural e histórica, diríamos, provavelmente só contornável através de um qualquer «choque térmico», como, por exemplo, a introdução, com força constitucional, da obrigatoriedade de cumprir saldos correntes equilibrados, eventualmente depurados de medidas extraordinárias de relevo, ao invés do tradicional foco no saldo global, estrutural ou não. No fundo, confrontado com um volume de receita praticamente perto do seu limite, seria uma forma de abater seriamente despesa corrente, quiçá por via da eternamente adiada reforma do Estado.

Efetivamente, mais do que o volume da dívida pública, deveríamos debater a sua génese material a nível nacional. Se pensarmos bem, no plano das relações privadas, quem no seu perfeito juízo empresta dinheiro a outrem para que este possa honrar o pagamento dos juros das dívidas que contraiu em tempos? É por isso importante obter quanto antes - sob pena de voltarmos a ver os senhores do fraque e entrar altivamente no Ministério das Finanças - uma ampla convergência na sociedade civil no sentido de controlar os principais focos de destabilização orçamental que atropelam esse desiderato. Falamos, essencialmente, do ainda elevado índice de massa adiposa do Estado, o peso crescente das pensões de velhice, os gastos exponenciais no setor da saúde e o volume assustador de encargos com a dívida pública, ainda com uma taxa implícita muito pesada face a países ocidentais com uma situação comparável à nossa. Isto contando que o ainda fragilizado setor bancário não traga mais surpresas desagradáveis.

Por outro lado, assume também especial preocupação o facto de a dívida pública portuguesa, depois de ser maioritariamente baseada em entidades residentes de natureza não especulativa (populares e investidores institucionais sem pretensões especulativas), o que conferia à sua remuneração atual e futura uma forte previsibilidade e estabilidade, ter-se posicionado num quadrante de elevada instabilidade, onde os investidores institucionais com fins de rentabilização de capitais próprios e alheios, maioritariamente externos, assumem a «fatia de leão». Estes, baseados em avaliações de agências de rating com critérios nem sempre percetíveis ou até algo opacos, não raras vezes tendo por base razões de ordem 
ideológica e preconceituosa, com um poder de influência transnacional ao mais alto nível, acabam sempre por criar dependências nos países devedores, que se veem assim desprovidos de parte da sua soberania nacional. Neste aspeto, as próprias estâncias da União Europeia têm dado exemplos que não podem ser considerados absolutamente felizes, sendo cada vez mais indisfarçáveis os tratamentos diferenciados entre grandes e pequenos países.

Por outro lado, o facto de a maioria dos credores ser entidades não residentes - muito à conta de um secular défice externo, em especial na balança de bens, bem como, mais recentemente, de uma significativa quebra da poupança interna - faz com que exista uma transferência de riqueza do país para o exterior, o que não acontece quando a dívida é maioritariamente interna. Os riscos para a autonomia e até para a segurança estratégica de uma nação aumentam quando os principais devedores estão alinhados com pretensões do foro geoeconómico ou até geopolítico de outros países mais interventivos na senda mundial, já que aquela acaba por ser, de uma forma ou de outra, uma mera plataforma para os seus interesses expansionistas. Daí que se torne especialmente importante, quando se assiste a uma reconfiguração geopolítica à escala global, que as autoridades portuguesas mitiguem as vulnerabilidades nacionais neste domínio, podendo começar por diminuir o peso da componente de dívida pública externa negociável ${ }^{51}$.

Talvez a substituição paulatina da dívida da troika, para além de toda a outra que irá rolar no futuro, seja uma oportunidade para cativar investidores residentes a adquirirem títulos do tesouro que efetivamente sejam atrativos do ponto de vista remuneratório face aos tradicionais produtos sucedâneos, como por exemplo os depósitos a prazo. Tal como, obviamente, a prossecução do tão almejado crescimento económico sustentado, essencialmente à base de mais exportações, menos importações e, associado a isso, investimento com a menor incorporação possível de bens e serviços externos.

\section{BIBLIOGRAFIA}

FERNANDES, Abel Costa, Economia Pública - Eficiência Económica e Teoria das Escolhas Públicas, Edições

Sílabo, 2. ${ }^{a}$ Edição, Lisboa, 2011

ABREU, Alexandre et al., A Crise, a Troika e as Alternativas Urgentes, Tinta da China, Lisboa, 2013

Andrew White and David Uren, Ausgrid sale: China's State Grid prowls worldwide for assets, in The Australian

Business Review (09/08/2016)

Fernando Alexandre, Luis Aguiar-Conraria e Pedro Bação, Crise e Castigo, FMS, Lisboa, 2016

José Félix Ribeiro, Portugal, a Economia de uma Nação Rebelde, Guerra e Paz Editores, 2. Edição, Lisboa, 2014 
Carlos Moreno, Finanças Públicas - Gestão, Controlo e Auditoria dos Dinheiros Públicos, UAL, 3. ${ }^{a}$ Edição, Lisboa, 2006

Domingos Pereira de Sousa, Finanças Públicas, ISCSP, Lisboa, 1992

Eduardo Paz Ferreira et al., A austeridade cura? A austeridade mata?, Lisbon Law School Editions, Lisboa, 2013 Emanuel Augusto dos Santos, Sem Crescimento Não Há Consolidação Orçamental, Edições Sílabo, Lisboa,

2012

J. Albano Santos, Finanças Públicas, INA Editora, Oeiras, 2010

Jean-Claude Drouin, Os Grandes Economistas - Uma Introdução à Economia, Edições Texto \& Grafia, Lisboa, 2011

João César das Neves, As 10 Questões da Recuperação, D. Quixote, Alfragide, 2012

Jorge Correia de Cunha e Cláudia Braz, A Evolução da Despesa Pública: Portugal no Contexto da Área do Euro, Boletim de Inverno do Banco de Portugal, Lisboa, 2013

Jorge Nascimento Rodrigues, Portugal na Banca Rota, Centro Atlantico.pt, V. N. Famalicão, 2012

José Carlos Soares, Dicionário de Economia, Plátano Editora, Lisboa, 2008

José Teixeira Ribeiro, Lições de Finanças Públicas, Coimbra Editora, $5 .{ }^{a}$ Edição, Coimbra, 1997

José Torres, Não Temos de Ser Alemães, Editora Matéria-Prima, Lisboa, 2014

José Torres, Dívida Pública e Soberania Nacional, ISCPSI, Lisboa, 2017

Leonor Freire et al., História Económica de Portugal (1143-2010), A Esfera dos Livros, Lisboa 2011

Luciano Amaral, Economia Portuguesa - As Últimas Décadas, FFMS, Lisboa, 2010

Maria Inês Marques Ferreira Alves, O Pacto de Estabilidade e Crescimento, o Investimento Público e o desempenho das políticas orçamentais na União Europeia, Tese de Mestrado em Economia, Instituto Superior de Economia e Gestão, Universidade Técnica de Lisboa, 2004

Marco Buti, A sustentabilidade das Finanças Públicas e o PEC, apresentado na Conferência de 13 de Dezembro de 2004 «A sustentabilidade das finanças públicas no médio/longo prazo» da Comissão de Execução Orçamental, Assembleia da República, 2004

Paul Krugman, Acabem Com Esta Crise Já!, Editorial Presença, 3. Edição, Lisboa, 2012

Paulo Trigo Pereira, Portugal: Dívida Pública e Défice Democrático, FFMS, Lisboa, 2012

Philippe Askenazy et al., Manifesto dos Economistas Aterrados, Actual Editora, Lisboa, 2011

Relatórios Anuais do Banco de Portugal e principais documentos orçamentais da DGO (Orçamento e Conta Geral do Estado) 